\title{
Burchellin: study of bioactivity against Aedes aegypti
}

Juliana Oliveira Abreu Narciso', Renata Oliveira de Araújo Soares², Jacenir Reis dos Santos Mallet ${ }^{3}$, Anthony Érico Guimarães ${ }^{1}$, Maria Célia de Oliveira Chaves ${ }^{4}$, José Maria Barbosa-Filho ${ }^{4}$ and Marise Maleck ${ }^{1,5^{*}}$

\begin{abstract}
Background: The dengue mosquito Aedes aegypti Linnaeus, 1762 is a widespread insect pest of serious medical importance. Since no effective vaccine is available for treating dengue, the eradication or control of the main mosquito vector is regarded as essential. Since conventional insecticides have limited success, plants may be an alternative source of larvicidal agents, since they contain a rich source of bioactive chemicals. The aim of this study was to evaluate the larvicidal activity of the neolignan burchellin isolated from Ocotea cymbarum (Lauraceae), a plant from the Amazon region, against third instar larvae of $A$. aegypti.

Methods: Burchellin obtained from O. cymbarum was analyzed. The inhibitory activity against A. aegypti eggs and larvae and histological changes in the digestive system of treated L3 larvae were evaluated. In addition, nitric oxide synthase activity and nitric oxide levels were determined, and cytotoxicity bioassays performed.

Results: The data showed that burchellin interfered with the development cycle of the mosquito, where its strongest toxic effect was 100\% mortality in larvae (L3) at concentrations $\geq 30 \mathrm{ppm}$. This compound did not show target cell toxicity in peritoneal macrophages from BALB/c mice, and proved to have molecular stability when dissolved in water. The $L 3$ and L4 larvae treated with the compound showed cellular destruction and disorganization, cell spacing, and vacuolization of epithelial cells in small regions of the midgut.
\end{abstract}

Conclusion: The neolignan burchellin proved to be a strong candidate for a natural, safe and stable phytolarvicidal to be used in population control of A. aegypti.

Keywords: Dengue, Aedes aegypti (L.), Neolignan burchellin, Ocotea cymbarum (Lauraceae), Larvicidal activity

\section{Background}

Aedes (Stegomyia) aegypti Linnaeus, 1762, whose main medical importance is due to its spread in urban areas and vector capacity for dengue virus [1], is responsible for frequent epidemics caused by the migration of the four serotypes within the Americas [2]. Females of the classic dengue vector, $A$. aegypti distribute their eggs among several oviposition sites and have a great capacity for adaptation to adverse conditions [3,4], making the control of this vector very difficult. The application of insecticides is undermined by its diurnal hematophagous

\footnotetext{
* Correspondence: mmaleck@oi.com.br

'Laboratório de Diptera, Instituto Oswaldo Cruz, FIOCRUZ, Av. Brazil 4365, Rio de Janeiro 21045-900, Brazil

${ }^{5}$ Laboratório de Insetos Vetores, Ciências da Saúde and Mestrado Profissional em Ciências Ambientais, Universidade Severino Sombra, Av. Expedicionário

Oswaldo de Almeida Ramos, 280, 27700-000 Vassouras, RJ, Brazil

Full list of author information is available at the end of the article
}

habits and the inherent complexity of its control in urban centers [1].

Several studies have drawn attention to natural products with larvicidal activity that could be useful in controlling many vectors [5-7], including A. aegypti [6,8,9]. The mode of action of natural insecticides is variable. While some of them inhibit normal growth and development [10-12], others inhibit the synthesis of tyrosinase, an enzyme involved in sclerotization of the cuticle, such as in the case of Culex quinquefasciatus larvae [13], or act as an antidiuretic hormone [14] and reduce reproductive capacity [15]. Plant extracts and phytochemicals have potential as products for mosquito control because many of them are selective, may often biodegrade to nontoxic products, and may be applied to mosquito breeding places in the same way as conventional insecticides [16-18]. Several studies have been carried out on lignans and their

\section{Biomed Central}


effects on insects $[7,11,12,14,15,19]$, indicating that they could be larvicidal against $A$. aegypti [9]. The neolignans eupomatenoid-6, eupomatenoid-5 and conocarpan, isolated from the leaves of Piper decurrens A.DC. 1866 (Piperaceae), have demonstrated significant larval toxicity against $A$. atropalpus Coquillett, 1902 [20]. A potent reducing agent and antioxidant known as nor-dihydroguaiareticacid (NDGA), when added to the axenic larval medium or diet of adult mosquitoes of $A$. aegypti, has shown an increased life time (longevity) of adult insects [21].

Thus, the aim of this study was to determine the toxicity of burchellin and its morphological effects on the digestive system in immature forms (L3) of A. aegypti.

\section{Methods}

\section{Isolation of burchellin}

Burchellin derived from O. cymbarum collected in Belem, Para, was studied for its larvicidal activity. The botanical material was identified at Hamburg University, Germany, by Prof. Klaus Kubitzhi, and the neolignan burchellin (Figure 1) was purified from aerial parts of O. cymbarum [22]. A specimen from a small island of the lower Rio Negro, Amazonas, was collected and identified by Prof. K. Kubitzki, Hamburg. A voucher specimen (58576) was deposited at the Herbarium INPA, Manaus. Burchellin was isolated for the first time in 1972 from Aniba burchelli [23]. Its synthesis is described in the literature [24] and the compound was identified by ${ }^{1} \mathrm{H}$ and ${ }^{13} \mathrm{C}$ nuclear magnetic resonance. One-dimensional $\left({ }^{1} \mathrm{H}\right.$ and $\left.{ }^{13} \mathrm{C}\right)$ and twodimensional (gHMQC, gHMBC, gCOSY and gNOESY) NMR analyses were performed on a Varian System spectrometer operating at $500 \mathrm{MHz}\left({ }^{1} \mathrm{H}\right)$ and $125 \mathrm{MHz}\left({ }^{13} \mathrm{C}\right)$. $\mathrm{CDCl}_{3}$ was used as the solvent with TMS (tetramethylsilane) as an internal standard. HRESIMS (high resolution electro spray ionization mass spectrometry) was carried out using a micrOTOF-II system from Bruker.

In this study, the dry and powdered stem (253 g) was extracted with hexane, dichloromethane and ethanol in a Soxhlet apparatus. The resultant solutions were filtered

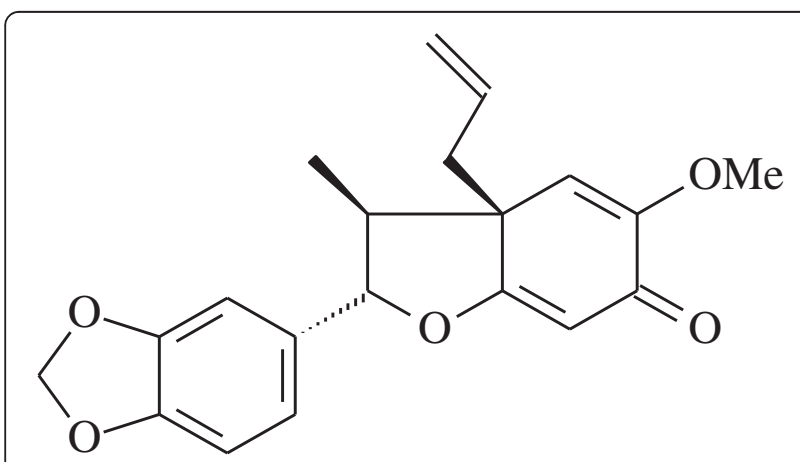

Figure 1 Burchellin, neolignan from Ocotea cymbarum Kunth, Lauraceae. and concentrated in a rotary evaporator under reduced pressure, providing $4.2 \mathrm{~g}$ hexane extract, $1.90 \mathrm{~g}$ dichloromethane extract and $11.0 \mathrm{~g}$ ethanolic extract. The hexane extract was chromatographed on an $\mathrm{H}-60$ silica gel column (Merck) using mixtures of chloroform and methanol of increasing polarity under pressure of $2 \mathrm{kgf} / \mathrm{cm}^{2}$ in a nitrogen atmosphere. Fractions 3 - 5 (411.9 mg) were pooled and rechromatographed on a silica gel 60 column (Merck) using a mixture of hexane and ethyl acetate of increasing polarity. Elution with hexane: ethylacetate (7:3) gave a fraction that was later subjected to HPLC, utilizing ethyl acetate: hexane (28:72) as the eluent, with a flow rate of $13 \mathrm{~mL} / \mathrm{min}$, and a Perkin-Elmer Si-6C column $(250 \times 16 \mathrm{~mm}$, particle size of $10 \mu \mathrm{m})$, and UV detector at $260 \mathrm{~nm}$ [22]. The burchellin obtained was recrystallized from a mixture of hexane: ethylacetate and then with acetone, resulting in $287.1 \mathrm{mg}$ of white crystals with a melting point of $150^{\circ} \mathrm{C}$, as determined according to Araújo-Lima [23].

\section{Biosssays}

A. aegypti eggs were obtained from the Vector Research and Support Center/NApVE (partnership DIRAC-IOCVPAAPS), Oswaldo Cruz Institute, FIOCRUZ, Rio de Janeiro and were kept in the Diptera Laboratory of Oswaldo Cruz Institute, FIOCRUZ, Rio de Janeiro, in which a colony was also maintained. The bioassays were carried out using eggs that were placed in a receptacle containing mineral water with fish food ( $0.3 \mathrm{mg} / \mathrm{larva})$ (Alcon Guppy) for hatching [9,25]. All experiments were carried out on third instar (L3) larvae (F1-F5) in triplicate with three repetitions, to determine the effect of the neolignan.

Burchellin was dissolved in acetone and diluted 1:4 in $0.15 \mathrm{M} \mathrm{NaCl}$ at final concentrations of $0.001-300 \mathrm{ppm}$. The burchellin solutions were used in the treatment of the larval groups and individual larvae. In larval group treatment, with 10 larvae per group, burchellin was added to glass containers $(4.0 \mathrm{~cm} \times 4.5 \mathrm{~cm})$ containing mineral water $(10 \mathrm{~mL})$ at final concentrations of $0.5,1$, 5, 10, 20, 30, 100, 200 and $300 \mathrm{ppm}$. In individualized larval treatment, with 20 individual larvae per group, the compound was added to glass containers $(2.0 \mathrm{~cm} \times 4.0 \mathrm{~cm})$ containing mineral water $(5 \mathrm{~mL})$ at final concentrations of $0.001,0.01,0.1,0.3,0.5,1,3.8,5,10,30,50,100,150$ and $300 \mathrm{ppm}$. A. aegypti larval (L3) groups and individuals (F1-F5) were evaluated in triplicate with three repetitions, as described elsewhere $[9,25]$ and adapted from WHO [26]. Two control groups included one with acetone solution (without burchellin) and another with untreated solution. The bioassays were maintained in a climatecontrolled chamber at $28 \pm 1^{\circ} \mathrm{C}, 70 \pm 10 \%$ relative humidity and 12-h photoperiod throughout the experiments, 
and toxicity against $A$. aegypti larvae and their growth development were evaluated until completely adults.

The data were analyzed using the ANOVA F-test [27] and $x^{2}$ test, where $P \leq 0.05$ and $P \leq 0.01$ were considered significant, respectively. Standard deviations were calculated using the averages from the experiments using GraphPad Instat 3.05 [28] and Trimmed Spearman-Karber analysis to determine the LC50 [29].

\section{Chemical stability in water vs biological activity}

To evaluate toxicity according to the duration of the substance dissolved in medium used for rearing larvae, $15 \mathrm{ppm}$ burchellin was added to mineral water without the presence of $A$. aegypti larvae. Ten larvae (L3) per group were added to the previously treated medium, according to the periods of incubation of the product $(12,24,48,72,96$ and $120 \mathrm{~h})$, including the control groups. After $1 \mathrm{~h}$ exposure, the larvae were given fish meal $(0.3 \mathrm{mg} / \mathrm{mL})$. In case of mortality, the larvae were removed from the test medium.

To evaluate the duration of biological activity of the test compound in solution, burchellin at $30 \mathrm{ppm}$ was added to the larval rearing medium in the presence of $A$. aegypti larvae $(\mathrm{n}=100)$. After 1hexposure to the substance, the larvae were given fish meal $(0.3 \mathrm{mg} / \mathrm{mL})$. The larvae $(n=10)$, live or dead, were removed after different periods $(1,2,3,24,48$ and $76 \mathrm{~h})$ of contact with the compound, and transferred to medium without burchellin, including control and acetone control. Larval mortality was assessed according to the time of exposure to the neolignan, to determine the minimal and maximal period of action of the compound on the A. aegypti larvae. All bioassays were carried out in a climate-controlled chamber at $28 \pm 1^{\circ} \mathrm{C}, 70 \pm 10 \%$ relative humidity and $12 \mathrm{~h}$ photoperiod.

\section{Histology - digestive system}

A histological evaluation of the digestive system was performed using L3 larvae (treated, control and acetone control) fixed in $2.5 \%$ glutaraldehyde in sodium cacodylate buffer $(0.1 \mathrm{M}, \mathrm{pH} 7.4)$ for $4 \mathrm{~h}$. They were then dehydrated with increasing concentrations of ethanol (70, 80, 90, 96 and 100\%), by immersion in each of these solutions for 15 min. Next, they were embedded in Historesin JB4 and the resultant blocks were sliced using a microtome to obtain a series of 3- $\mu \mathrm{m}$ thick sections. These sections were stained with hematoxylin-eosin, and then examined and photographed using a light microscope [30].

\section{Nitric oxide synthase (NOS) assay}

Nitric oxide synthase activity was measured utilizing the protocol previously described [31]: total intestinal cells of the larvae (L3) of $A$. aegypti were recovered with trypsin/EDTA $(0.05 / 0.02 \%$ v/v; Sigma Chemical
Co.), washed and resuspended in $2 \mathrm{~mL}$ of HEPES buffer (pH 7.2; Sigma Chemical Co.). Protein concentration was $10.7 \mathrm{mg} / \mathrm{mL}$ as measured by spectrometry (260-280 nm). Next, the sample was mixed with a protease inhibitor cocktail, consisting of $0.1 \mathrm{mM}$ phenylmethylsulfonyl fluoride (PMSF), $0.01 \%$ leupeptin, $0.2 \mathrm{mg} / \mathrm{mL}$ trypsin inhibitor and $1.0 \mathrm{mM}$ benzamidine), in a final volume of $5 \mathrm{~mL}$ [31]. Aliquots of lysed cells were frozen in liquid nitrogen for later assay of NOS activity.

\section{NOS activity}

In each assay, intestinal homogenate containing $200 \mu \mathrm{g} / \mathrm{mL}$ protein was mixed with the following reagents (all from Sigma Chemical Co.) in a $400-\mu \mathrm{L}$ final volume: $0.2 \mathrm{mM}$ $\mathrm{NADPH}, 360 \mu \mathrm{M}$ L-arginine, $2 \mu \mathrm{M}$ tetrahydrobiopterin, $1.0 \mu \mathrm{M}$ FAD, $1.0 \mu \mathrm{M}$ FMN $, 0.3 \mathrm{mM} \mathrm{CaCl}_{2}, 0.2 \mathrm{mM}$ dithiothreitol and $50 \mathrm{mM}$ potassium phosphate buffer (pH 7.4). In some samples, the constitutive NOS inhibitor $L^{\omega}$-nitroL-arginine methyl ester (Sigma Chemical Co.), inducible NOS inhibitor diphenyliodonium chloride (Sigma Chemical Co.) and burchellin (1) $(20 \mu \mathrm{g} / \mathrm{mL})$ were added. A solution of acetone was used as a negative control and L-NAME as a positive control. NOS activity was determined in the reaction mixture by measuring the decrease in absorbance at $340 \mathrm{~nm}$ for $20 \mathrm{~min}$ continuously, and expressed as the amount of NADPH consumed during the enzymatic conversion of L-arginine to L-citrulline. Three independent experiments were performed, and the data obtained using different treatments were analyzed statistically by means of the Mann-Whitney test $(\mathrm{P}<0.05)$.

\section{Results}

Treatment of L3 larvae (in group) of $A$. aegypti with burchellin in rearing medium changed the period (in days) of larval and pupal development and emergence of adults at all concentrations tested when compared to the control groups and acetone control, mainly in the pupa phase of $A$. aegypti. Burchellin treatment in the group of L3 larvae caused a decrease in larval viability $(\mathrm{L} 3-\mathrm{L} 4)$ of $67 \%(6.7 \pm 1.5)(\mathrm{P}<0.001), 63 \%(6.3 \pm 1.1)$ $(\mathrm{P}<0.001), 66 \%(6.6 \pm 0.6)(\mathrm{P}<0.001)$ with concentrations of 5, 10 and $20 \mathrm{ppm}$, respectively. At $30 \mathrm{ppm}$, only $13 \%(1.3 \pm 0.6)(\mathrm{P}<0.001)$ of $\mathrm{L} 3$ larvae were viable. The emergence of adults (L3 - adult) was 67\% (6.7 \pm 1.5$)$ $(\mathrm{P}<0.001), 60 \%(6.0 \pm 1.0)(\mathrm{P}<0.001)$ and $40 \%(4.0 \pm 1.0)$ $(\mathrm{P}<0.001)$ at concentrations of $5-20 \mathrm{ppm}$ (Table 1A). The larvicidal activity of burchellin against $A$. aegypti was observed at a concentration of $30 \mathrm{ppm}$ with $100 \%$ larval mortality between 24 and $78 \mathrm{~h}$ after application of the compound (Table 1B). The neolignan showed a larval mortality of $33-53 \%$ at concentrations of $5-20 \mathrm{ppm}$ (Table $1 \mathrm{~B}$ ). These data resulted in an $\mathrm{LD}_{50}$ of $15.5 \mathrm{ppm}$ and $\mathrm{LD}_{90}$ of $27 \mathrm{ppm}$, using the trimmed Spearman-Karber method. 
Table 1 Viability (A) and mortality (B) of the A. aegypti group treated with burchellin

\begin{tabular}{|c|c|c|c|c|c|c|c|c|}
\hline \multirow[t]{2}{*}{ A } & \multicolumn{2}{|c|}{ L3-L4 } & \multicolumn{2}{|c|}{ L4 - Pupae } & \multicolumn{2}{|c|}{ Pupae -adult } & \multicolumn{2}{|c|}{ L3-Adult } \\
\hline & $X \pm S D$ & $\%$ & $X \pm S D$ & $\%$ & $X \pm S D$ & $\%$ & $X \pm S D$ & $\%$ \\
\hline Control & $10.0 \pm 0$ & 100 & $10.0 \pm 0 \mathrm{a}$ & 100 & $10.0 \pm 0 \mathrm{a}$ & 100 & $10.0 \pm 0 \mathrm{a}$ & 100 \\
\hline Control 2 & $10.0 \pm 0$ & 100 & $10.0 \pm 0 \mathrm{ab}$ & 100 & $10.0 \pm 0 a b$ & 100 & $10.0 \pm 0 a b$ & 100 \\
\hline $0.5 \mu \mathrm{g} / \mathrm{mL}$ & $10.0 \pm 0$ & 100 & $10.0 \pm 0 \mathrm{ab}$ & 100 & $10.0 \pm 0 \mathrm{ab}$ & 100 & $10.0 \pm 0 \mathrm{ab}$ & 100 \\
\hline $1 \mu \mathrm{g} / \mathrm{mL}$ & $10.0 \pm 0$ & 100 & $10.0 \pm 0 \mathrm{ab}$ & 100 & $10.0 \pm 0 \mathrm{ab}$ & 100 & $10.0 \pm 0 \mathrm{ab}$ & 100 \\
\hline $5 \mu \mathrm{g} / \mathrm{mL}$ & $10,0 \pm 0$ & 67 & $6.7 \pm 1.5 c^{* * *}$ & 100 & $6.7 \pm 1.5 c^{* * *}$ & 100 & $6.7 \pm 1.5 c^{* * *}$ & 67 \\
\hline $10 \mu \mathrm{g} / \mathrm{mL}$ & $10.0 \pm 0$ & 63 & $6.3 \pm 1.1 c^{* * *}$ & 100 & $6.3 \pm 1.1 \mathrm{~cd}^{* * *}$ & 95 & $6.0 \pm 1.0 \mathrm{~cd}^{* * *}$ & 60 \\
\hline $20 \mu \mathrm{g} / \mathrm{mL}$ & $10.0 \pm 0$ & 66 & $6.6 \pm 0.6 c^{* * *}$ & 71 & $4.7 \pm 0.6 d^{* * *}$ & 85 & $4.0 \pm 1.0 d^{* * *}$ & 40 \\
\hline $30 \mu \mathrm{g} / \mathrm{mL}$ & $10.0 \pm 0$ & 13 & $1.3 \pm 0.6 d^{* * *}$ & 0 & 0 & 0 & 0 & 0 \\
\hline \multirow[t]{2}{*}{ B } & \multicolumn{4}{|c|}{ Larvae } & \multicolumn{4}{|c|}{ Pupae } \\
\hline & \multicolumn{2}{|c|}{$X \pm S D$} & VI & $\%$ & $X \pm S D$ & VI & \multicolumn{2}{|c|}{$\%$} \\
\hline Control & \multicolumn{2}{|c|}{0} & 0 & 0 & 0 & 0 & \multicolumn{2}{|l|}{0} \\
\hline Control 2 & \multicolumn{2}{|c|}{0} & 0 & 0 & 0 & 0 & \multicolumn{2}{|l|}{0} \\
\hline $0.5 \mu \mathrm{g} / \mathrm{mL}$ & \multicolumn{2}{|c|}{0} & 0 & 0 & 0 & 0 & \multicolumn{2}{|l|}{0} \\
\hline $1 \mu \mathrm{g} / \mathrm{mL}$ & \multicolumn{2}{|c|}{0} & 0 & 0 & 0 & 0 & \multicolumn{2}{|l|}{0} \\
\hline $5 \mu \mathrm{g} / \mathrm{mL}$ & \multicolumn{2}{|c|}{$3.3 \pm 1.5 c^{* *}$} & $3-3$ & 33 & 0 & 0 & \multicolumn{2}{|l|}{0} \\
\hline $10 \mu \mathrm{g} / \mathrm{mL}$ & \multicolumn{2}{|c|}{$3.6 \pm 1.2 c^{* * *}$} & $2-2$ & 37 & $0.3 \pm 0.6$ & $7-7$ & \multicolumn{2}{|l|}{5} \\
\hline $20 \mu \mathrm{g} / \mathrm{mL}$ & \multicolumn{2}{|c|}{$5.7 \pm 0.2 c^{* * *}$} & $1-3$ & 53 & $0.7 \pm 0.6$ & $7-7$ & \multicolumn{2}{|c|}{14} \\
\hline $30 \mu \mathrm{g} / \mathrm{mL}$ & \multicolumn{2}{|c|}{$10 \pm 0 d^{* * *}$} & $1-3$ & 100 & - & - & \multicolumn{2}{|l|}{-} \\
\hline
\end{tabular}

Burchellin treatment on $A$. aegypti at $0.5-30 \mu \mathrm{g} / \mathrm{mL}$ concentration. Values are mean \pm standard deviation (X $\pm \mathrm{SD})$, average of three replicates of 10 larvae $\mathrm{L} 3$ per each group. Values followed by the same letter did not significantly different from each other, $\mathrm{P}>0.05$ when the Tukey test was used. Significance levels are represented as ${ }^{* *} \mathrm{P}<0.001$ and ${ }^{* *} \mathrm{P}<0.01$ vs. Control $2=$ Acetone control.

The individual treatment of larvae (L3) with burchellin showed 100 to $30 \%$ larval viability (L3-L4), and emergence of adults at increasing concentrations of the test substance (0.001 and $0.5 \mathrm{ppm}$ ) (Table 2A). The same concentrations showed from zero to $70 \%$ larval mortality (Table 2B). These data indicated that the concentrations below $0.5 \mu \mathrm{g} / \mathrm{mL}$ did not have any larvicidal effect, but interfered with the development of the insect.

The treatment of individual larvae (L3) with the lignan at concentrations of $1-10$ ppm significantly reduced the development of the mosquitoes (L3- adult), resulting in only $27 \%(2.3 \pm 1.2)(\mathrm{P}<0.001), 15 \%(1.3 \pm 1.5)(\mathrm{P}<0.001)$, $8 \%(0.7 \pm 0.6) \quad(\mathrm{P}<0.001)$, and $7 \%(0.7 \pm 0.6) \quad(\mathrm{P}<0.001)$ adults (Table 3A). Larval mortality of $A$. aegypti was observed by toxicity of 63 to $90 \%(\mathrm{P}<0.001)$ for $1-10 \mathrm{ppm}$ burchellin (Table 3B). The bioassays utilizing a concentration of $30 \mathrm{ppm}$ showed the larvicidal activity of burchellin with $100 \%$ larval mortality from 24 to $72 \mathrm{~h}$ after treatment $(\mathrm{P}<0.001)$ (Table 3B). The control groups and control appeared normal and did not show mortality. The data resulted in an $\mathrm{LC}_{50}$ of $0.4 \mathrm{ppm}$ and $\mathrm{LC}_{90}$ of $5 \mathrm{ppm}$, using the trimmed Spearman-Karber method.

\section{Chemical stability in water vs biological activity}

The activity assays of burchellin added to larval rearing medium for different periods of exposure showed a mortality of $17 \%$ at $12 \mathrm{~h}$ and $10 \%$ at up to $24 \mathrm{~h}$ of exposure. Burchellin did not demonstrate toxicity after $48 \mathrm{~h}$ of incubation in water, suggesting a possible loss of toxicity towards $A$. aegypti after $48 \mathrm{~h}$ in aqueous solution (Table 4A).

The burchellin absorption assays (hours) in larvae for different periods showed a $100 \%$ mortality only after exposure to the "medium + product" solution and for at least $48 \mathrm{~h}$. These data suggest the need for exposure of larvae to a minimum period of $48 \mathrm{~h}$ for absorption of the test compound (Table 4B).

\section{Histomorphology}

Histological analysis of the mosquito larvae of the control groups showed the three regions of the digestive tract (anterior, middle and posterior) with normal appearance and without morphological alterations. The epithelial cells of the anterior region were arranged in a single layer of short cylindrical cells and with an apical surface, demonstrating a thin line representing the brush border, also showing gastric caeca with normal appearance (Figure 2A, 2E). The peritrophic membrane showed a fine membrane completely surrounding all the alimentary content (Figure 2B, 2F). In the middle region of the intestine, the epithelial cells appeared a little taller with the cytoplasm preserved, while the brush border was a 
Table 2 Viability (A) and mortality (B) of the A. aegypti individual treatment with burchellin

\begin{tabular}{|c|c|c|c|c|c|c|c|c|}
\hline \multirow[t]{2}{*}{ A } & \multicolumn{2}{|c|}{ L3-L4 } & \multicolumn{2}{|c|}{ L4 - Pupae } & \multicolumn{2}{|c|}{ Pupae -adult } & \multicolumn{2}{|c|}{ L3-Adult } \\
\hline & $X \pm S D$ & $\%$ & $X \pm S D$ & $\%$ & $\mathrm{X} \pm \mathrm{SD}$ & $\%$ & $X \pm S D$ & $\%$ \\
\hline Control & $10.0 \pm 0$ & 100 & $10.0 \pm 0 a$ & 100 & $10.0 \pm 0 a$ & 100 & $10.0 \pm 0 a$ & 100 \\
\hline Control 2 & $10.0 \pm 0$ & 100 & $10.0 \pm 0 a b$ & 100 & $10.0 \pm 0 a b$ & 100 & $10.0 \pm 0 a b$ & 100 \\
\hline $0.001 \mu \mathrm{g} / \mathrm{mL}$ & $10.0 \pm 0$ & 100 & $10.0 \pm 0 a b$ & 100 & $10.0 \pm 0 a b$ & 100 & $10.0 \pm 0 a b$ & 100 \\
\hline $0.01 \mu \mathrm{g} / \mathrm{mL}$ & $10.0 \pm 0$ & 100 & $10.0 \pm 0 a b$ & 77 & $7.5 \pm 0.6 d^{* * *}$ & 100 & $7.5 \pm 0.6 d^{* * *}$ & 77 \\
\hline $0.1 \mu \mathrm{g} / \mathrm{mL}$ & $10.0 \pm 0$ & 100 & $10.0 \pm 0 a b$ & 73 & $7.3 \pm 0.6 d^{* * *}$ & 100 & $7.3 \pm 0.6 d^{* * *}$ & 73 \\
\hline $0.3 \mu \mathrm{g} / \mathrm{mL}$ & $10.0 \pm 0$ & 100 & $10.0 \pm 0 a b$ & 67 & $6.6 \pm 0.6 d^{* * *}$ & 100 & $6.6 \pm 0.6 d^{* * *}$ & 67 \\
\hline $0.5 \mu \mathrm{g} / \mathrm{mL}$ & $10.0 \pm 0$ & 100 & $10.0 \pm 0 a b$ & 30 & $3.0 \pm 1.0 c^{* * *}$ & 100 & $3.0 \pm 1.0 c^{* * *}$ & 30 \\
\hline \multirow[t]{2}{*}{ B } & \multicolumn{2}{|c|}{ Larvae } & & & \multicolumn{3}{|c|}{ Pupae } & \\
\hline & $X \pm S D$ & VI & $\%$ & & $X \pm S D$ & & VI & $\%$ \\
\hline Control & 0 & 0 & 0 & & 0 & & 0 & 0 \\
\hline Control 2 & 0 & 0 & 0 & & 0 & & 0 & 0 \\
\hline $0.001 \mu \mathrm{g} / \mathrm{mL}$ & 0 & 0 & 0 & & 0 & & 0 & 0 \\
\hline $0.01 \mu \mathrm{g} / \mathrm{mL}$ & $2.4 \pm 0.6 c^{* *}$ & $2-2$ & 23 & & 0 & & 0 & 0 \\
\hline $0.1 \mu \mathrm{g} / \mathrm{mL}$ & $2.6 \pm 0.6 c^{* *}$ & $2-2$ & 27 & & 0 & & 0 & 0 \\
\hline $0.3 \mu \mathrm{g} / \mathrm{mL}$ & $3.3 \pm 0.6 c^{* * *}$ & $2-3$ & 33 & & 0 & & 0 & 0 \\
\hline $0.5 \mu \mathrm{g} / \mathrm{mL}$ & $7.0 \pm 1.0 \mathrm{~d}^{* * *}$ & $2-3$ & 70 & & 0 & & 0 & 0 \\
\hline
\end{tabular}

Burchellin treatment on $A$. aegypti at $0.001-0.5 \mu \mathrm{g} / \mathrm{mL}$ concentration. Values are mean \pm standard deviation $(\mathrm{X} \pm \mathrm{SD})$, average of three replicates of 10 larvae $\mathrm{L} 3$ per each group. Values followed by the same letter did not significantly different from each other, $\mathrm{P}>0.05$ when the Tukey test was used. Significance levels are represented as ${ }^{* * P}<0.001$ and ${ }^{*} \mathrm{P}<0.05$ vs. Control $2=$ Acetone control. $\mathrm{NO}=$ not observed.

Table 3 Viability (A) and mortality (B) of the A. aegypti individual treatment with burchellin

\begin{tabular}{|c|c|c|c|c|c|c|c|c|}
\hline \multirow[t]{2}{*}{$A$} & \multicolumn{2}{|c|}{ L3-L4 } & \multicolumn{2}{|c|}{ L4 - Pupae } & \multicolumn{2}{|c|}{ Pupae -adult } & \multicolumn{2}{|c|}{ L3-Adult } \\
\hline & $X \pm S D$ & $\%$ & $\mathrm{X} \pm \mathrm{SD}$ & $\%$ & $\mathrm{X} \pm \mathrm{SD}$ & $\%$ & $X \pm S D$ & $\%$ \\
\hline Control & $10.0 \pm 0$ & 100 & $10.0 \pm 0 \mathrm{a}$ & 100 & $10.0 \pm 0 a$ & 100 & $10.0 \pm 0 a$ & 100 \\
\hline Control 2 & $10.0 \pm 0$ & 100 & $10.0 \pm 0 a b$ & 100 & $10.0 \pm 0 a b$ & 100 & $10.0 \pm 0 a b$ & 100 \\
\hline $0.5 \mu \mathrm{g} / \mathrm{mL}$ & $10.0 \pm 0$ & 87 & $8.7 \pm 0.6 \mathrm{ab}$ & 35 & $3.0 \pm 1.0 c^{* * *}$ & 100 & $3.0 \pm 1.0 c^{* * *}$ & 30 \\
\hline $1 \mu \mathrm{g} / \mathrm{mL}$ & $10.0 \pm 0$ & 87 & $8.7 \pm 0.6 \mathrm{ab}$ & 42 & $3.7 \pm 2.0 c^{* * *}$ & 64 & $2.3 \pm 1.2 c^{* * *}$ & 27 \\
\hline $3.8 \mu \mathrm{g} / \mathrm{mL}$ & $10.0 \pm 0$ & 90 & $9.0 \pm 1.7 \mathrm{ab}$ & 22 & $2.0 \pm 2.0 c^{* * *}$ & 67 & $1.3 \pm 1.5 c^{* * *}$ & 15 \\
\hline $5 \mu \mathrm{g} / \mathrm{mL}$ & $10.0 \pm 0$ & 87 & $8.3 \pm 1.2 \mathrm{ab}$ & 12 & $1.0 \pm 1.0 c^{* * *}$ & 67 & $0.7 \pm 0.6 c^{* * *}$ & 8 \\
\hline $10 \mu \mathrm{g} / \mathrm{mL}$ & $10.0 \pm 0$ & 27 & $2.7 \pm 1.2 c^{* * *}$ & 38 & $1.0 \pm 1.0 c^{* * *}$ & 67 & $0.7 \pm 0.6 c^{* * *}$ & 7 \\
\hline $30 \mu \mathrm{g} / \mathrm{mL}$ & $10.0 \pm 0$ & 20 & $2.0 \pm 0 c^{* * *}$ & 0 & 0 & 0 & 0 & 0 \\
\hline \multirow[t]{2}{*}{ B } & \multicolumn{3}{|c|}{ Larvae } & \multicolumn{5}{|c|}{ Pupae } \\
\hline & $X \pm S D$ & VI & $\%$ & $X \pm S D$ & VI & & $\%$ & \\
\hline Control & 0 & 0 & 0 & 0 & 0 & & 0 & \\
\hline Control 2 & 0 & 0 & 0 & 0 & 0 & & 0 & \\
\hline $0.5 \mu \mathrm{g} / \mathrm{mL}$ & $7 \pm 1 c^{* * *}$ & $3-38$ & 70 & 0 & 0 & & 0 & \\
\hline $1 \mu \mathrm{g} / \mathrm{mL}$ & $7 \pm 0 c^{* * *}$ & $2-31$ & 63 & 0 & 0 & & 0 & \\
\hline $3.8 \mu \mathrm{g} / \mathrm{mL}$ & $8 \pm 2 \mathrm{~cd}^{* * *}$ & $2-36$ & 80 & $0.7 \pm 1.2$ & $22-22 c$ & & 33 & \\
\hline $5 \mu \mathrm{g} / \mathrm{mL}$ & $9 \pm 0 \mathrm{~cd}^{* * *}$ & $2-39$ & 90 & $0.3 \pm 0.6$ & $18-18 c$ & & 33 & \\
\hline $10 \mu \mathrm{g} / \mathrm{mL}$ & $9 \pm 1 \mathrm{~cd}^{* * *}$ & $2-30$ & 90 & $0.3 \pm 0.6$ & $28-28 c$ & & 33 & \\
\hline $30 \mu \mathrm{g} / \mathrm{mL}$ & $10 \pm 0 c d^{* * *}$ & $2-4$ & 100 & 0 & 0 & & 0 & \\
\hline
\end{tabular}

Burchellin individual treatment on A. aegypti at $0.5-30 \mu \mathrm{g} / \mathrm{mL}$ concentration. Values are mean \pm standard deviation (X \pm SD), average of three replicates of 10 larvae L3 per each group. Values followed by the same letter did not significantly different from each other, P $>0.05$ when the Tukey test was used. Significance levels are represented as ${ }^{* *} \mathrm{P}<0.001$ vs. Control $2=$ Acetone control. 
Table 4 Evaluation of biological activity of burchellin against $A$. aegypti (L3)

\begin{tabular}{lcc}
\hline A & \multicolumn{2}{c}{ Mortality (L3 larvae) } \\
\cline { 2 - 3 } & $\mathbf{X} \pm$ SD & $\%$ \\
\hline Control & $\mathrm{a}$ & 0 \\
Control 2 & $\mathrm{b}$ & 0 \\
$12 \mathrm{~h}$ & $1.66 \pm 1.15 \mathrm{ab}^{* *}$ & 17 \\
$24 \mathrm{~h}$ & $1.0 \pm 0$ & 10 \\
$48 \mathrm{~h}$ & $1.0 \pm 0$ & 3 \\
$72 \mathrm{~h}$ & 0 & 0 \\
$96 \mathrm{~h}$ & 0 & 0 \\
$120 \mathrm{~h}$ & 0 & 0 \\
B & \multicolumn{1}{c}{ Mortality (L3 larvae) } & \\
\cline { 2 - 3 } & Number & $\%$ \\
\hline Control & 0 & 0 \\
Control 2 & 0 & 0 \\
$1 \mathrm{~h}$ & 0 & 0 \\
$2 \mathrm{~h}$ & 0 & 0 \\
$3 \mathrm{~h}$ & 0 & 0 \\
$24 \mathrm{~h}$ & 0 & 0 \\
$48 \mathrm{~h}$ & 60 & 100 \\
\hline Afer & 0 &
\end{tabular}

After 12-120 $\mathrm{h}(4 \mathrm{~A})$ and $1-48 \mathrm{~h}(4 \mathrm{~B})$ incubation, larvae in mid-development were treated with burchellin. Treatment of A. aegypti with $15 \mu \mathrm{g} / \mathrm{mL}$ burchellin using 10 L3 larvae per group (4A) and $30 \mu \mathrm{g} / \mathrm{mL}$ burchellin using 100 larvae (L3) per group (4B). Larvae $(n=10)$ were removed at intervals of 1 - $48 \mathrm{~h}$ (4B). All experiments were performed in triplicate. Values are mean \pm standard deviation $(X \pm S D)$. Values followed by the same letter did not differ significantly; Tukey test, $P>0.05$. Significance levels are represented as ${ }^{* *} \mathrm{P}<0.01$ vs. Control $2=$ Acetone control.

little thicker. This region contained some cells with a more globose appearance, similar to caliciform cells, and with a typical appearing nucleus (Figure 2C, 2G). The posterior region of the intestine showed for the most part cells with a laced appearance of the cytoplasm, displaying indentations and a thick brush border on the apical surface. Malpighian tubules and muscle tissue showed typical appearance (Figure 2D, 2H)).

The larvae treated with burchellin exhibited alterations in the middle intestine (Figure 3A, B, C) with evidence of cell destruction, vacuolization of epithelial cells, tissue disorganization with spacing between the cells and some rupture points of muscle tissue. There was an apparent accumulation of granules in some areas of the cytoplasm, and faint and/or absent nuclei (Figure 3D). Some cells showed a lack of cytoplasmic borders (Figure 3B, C, D and $\mathrm{E})$. Alterations in gastric caeca were also observed with the presence of vacuoles and cellular disorganization. The Malpighian tubules of the larvae treated with burchellin also showed alterations, namely the presence of vacuolated cells, spacing between the cells and clear or absent nucleus (Figure 3B and E).

\section{Discussion}

The results obtained in this study with the neolignan burchellin, isolated from the stem of O. cymbarumin the hexane fraction, demonstrated effective larvicidal activity against $A$. aegypti, indicating that the family Lauraceae harbors substances potentially bioactive against insects. Larvicidal activity of the neolignan with $50 \%$ mortality occurred at a concentration of $15.5 \mathrm{ppm}$ and with $100 \%$ mortality at $30 \mathrm{ppm}$, justifying the interest in this class of compounds or in the plant family in question. Studies indicate the presence of different biological activity in the genus Ocotea and that biomonitoring phytochemistry vs activity [32] can be confirmed by biological activities of insects [11,12], especially in the case of burchellin $[14,19]$. This was again confirmed in this study where burchellin showed toxicity in group and individual treatment of L3 larvae of $A$. aegypti.

With regard to the class of lignoids, neolignans have been shown to be effective against L1 larvae of $A$. aegypti, as evidenced by the larvicidal activity ( $\mathrm{LC} 50=2.37 \mu \mathrm{g} / \mathrm{mL}$ ) of grandisin, a neolignan isolated from the leaves of Piper solmsianum (Piperaceae) [9]. Similar activities have also been found for the neolignans eupomatenoid-6, eupomatenoid-5 and conocarpan against $A$. atropalpus Coq. [20]. The lignans epi-sesartemin and diayangambin isolated from Phryma leptostachya L. [33] and Piper fimbriulatum C. DC. have shown larvicidal activity against A. aegypti [34].

Analyses of the spectral data of four aliquots did not show structural differences in the molecule up to a period of $48 \mathrm{~h}$ when compared to data obtained with the original sample. The compound only underwent structural rearrangement when heated to $70^{\circ} \mathrm{C}$ in an oven [35]. These data showed that burchellin is a very stable compound in water and that it degrades only when subjected to high temperatures. Assays of activity vs exposure period demonstrated that $A$. aegypti larvae need constant contact with the neolignan for $100 \%$ mortality of immature forms (L3) up to $48 \mathrm{~h}$.

The histomorphological alterations in larvae treated with burchellin, which possibly resulted in the death of the larvae (L3-L4) of A. aegypti, could be observed in the middle region of the intestine, with cellular destruction and disorganization, spacing between cells and vacuolization of epithelial cells. Similar results as ours were obtained in histological analyses of Culex nigripalpus larvae infected by Bacillus thuringiensis medellin (Cry11Bb) [36] and in intestinal cells of larvae of Aedes albopictus infected with $B$. thuringiensis var. israelensis (Bti) [37]. The authors reported as signs of infection, the presence of rounded cells, cytoplasm with granules, clear or absent nucleus and extensive cytoplasmic vacuolization of epithelial cells of the mesentery of these larvae. 


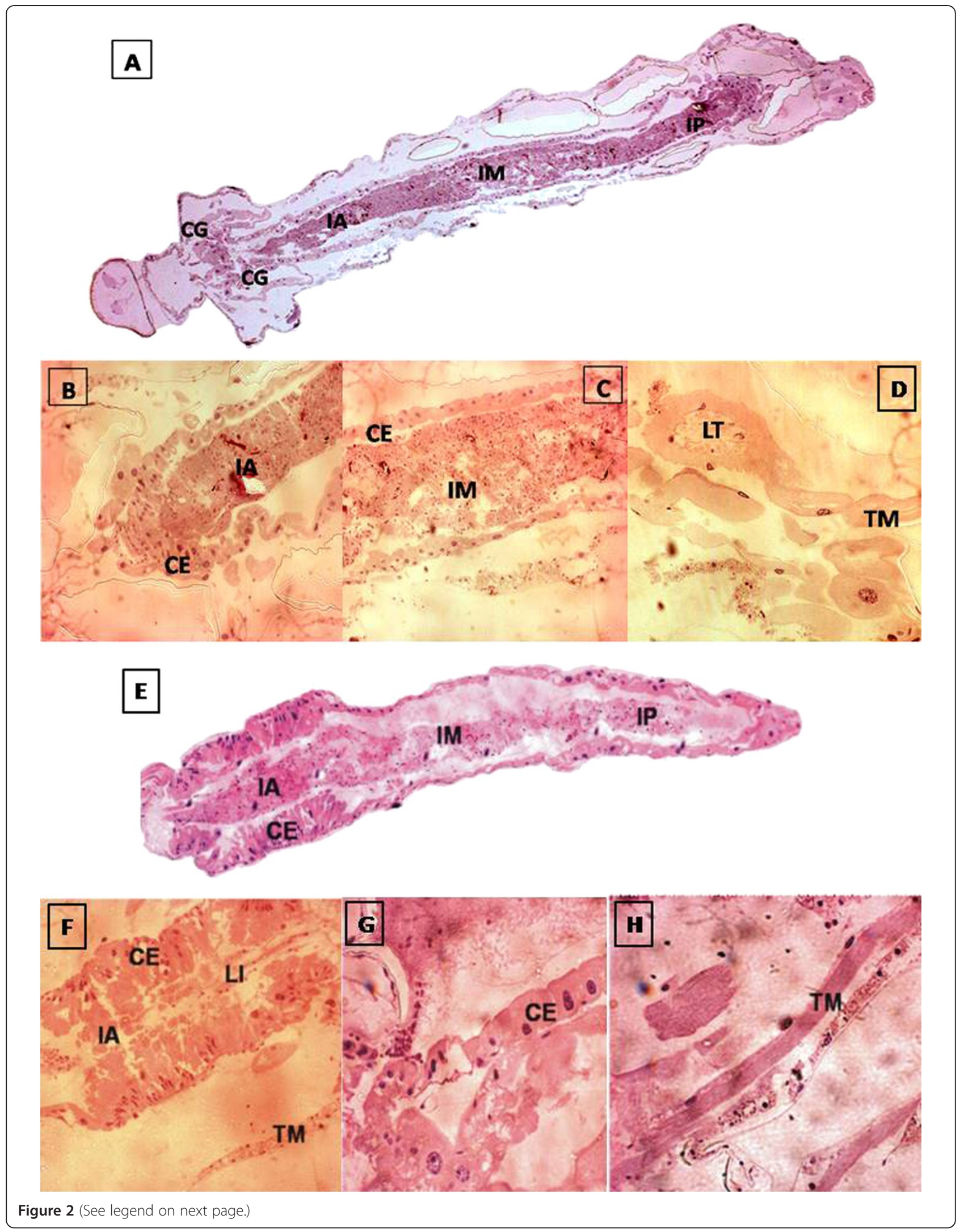


(See figure on previous page.)

Figure 2 Photomicrographs of the digestive tract of larvae of third instar of $\boldsymbol{A}$. aegypti maintained with food. Longitudinal sections stained with HE. A- D: control group. A. Overview. Gastric caeca (GC) foregut (IA), midgut (IM), hindgut (IP) 10X. B. Foregut details (IA) and intestinal epithelial cells (EC) 20×. C. Midgut (IM) and intestinal epithelial cells (EC) 20×. C. Detail of the Malpighian tubules (TM) and light of Malpighian tubule (LT) 20x. E - H: acetone group. E. Overview. Foregut (IA), midgut (IM), hindgut. (IP) and intestinal epithelial cells 20x. F. Foregut details (IA), intestinal lumen (LI) intestinal epithelial cells (EC) and muscle tissue (TM) 20x. G. Detail of intestinal epithelial cells (EC) 40X. H. Detail of muscle tissue (TM) 4X.

A. aegypti larvae treated with burchellin showed a large quantity of granules in some areas of the cytoplasm resulting in cell lysis. According to Snodgrass [38], the digestive cells of the mesentery of insects can generally participate actively in the processes of secretion and absorption. Disintegration of these cells occurs through the accumulation of granular material in the apical portion with release of this material into the intestinal lumen of the insect.

The mosquito larvae treated with the test substance also showed alterations in the gastric caeca, namely vacuolated cells, cellular disorganization with spacing between the cell membrane, and the nucleus being clear or absent. These tissue changes are not restricted to the use of chemicals since they were also observed in the gastric caeca and in the region of the Malpighian tubules of the larvae of Culex nigripalpus Theobald, 1901 exposed to baculovirus [36].

These histomorphological findings help us understand the toxicity of substances related to the site of action of burchellin in $A$. aegypti larvae; the resultant tissue degradation hampers the survival of the larvae.

In this study, the neolignan burchellin showed little degradation when added to water, making it even more
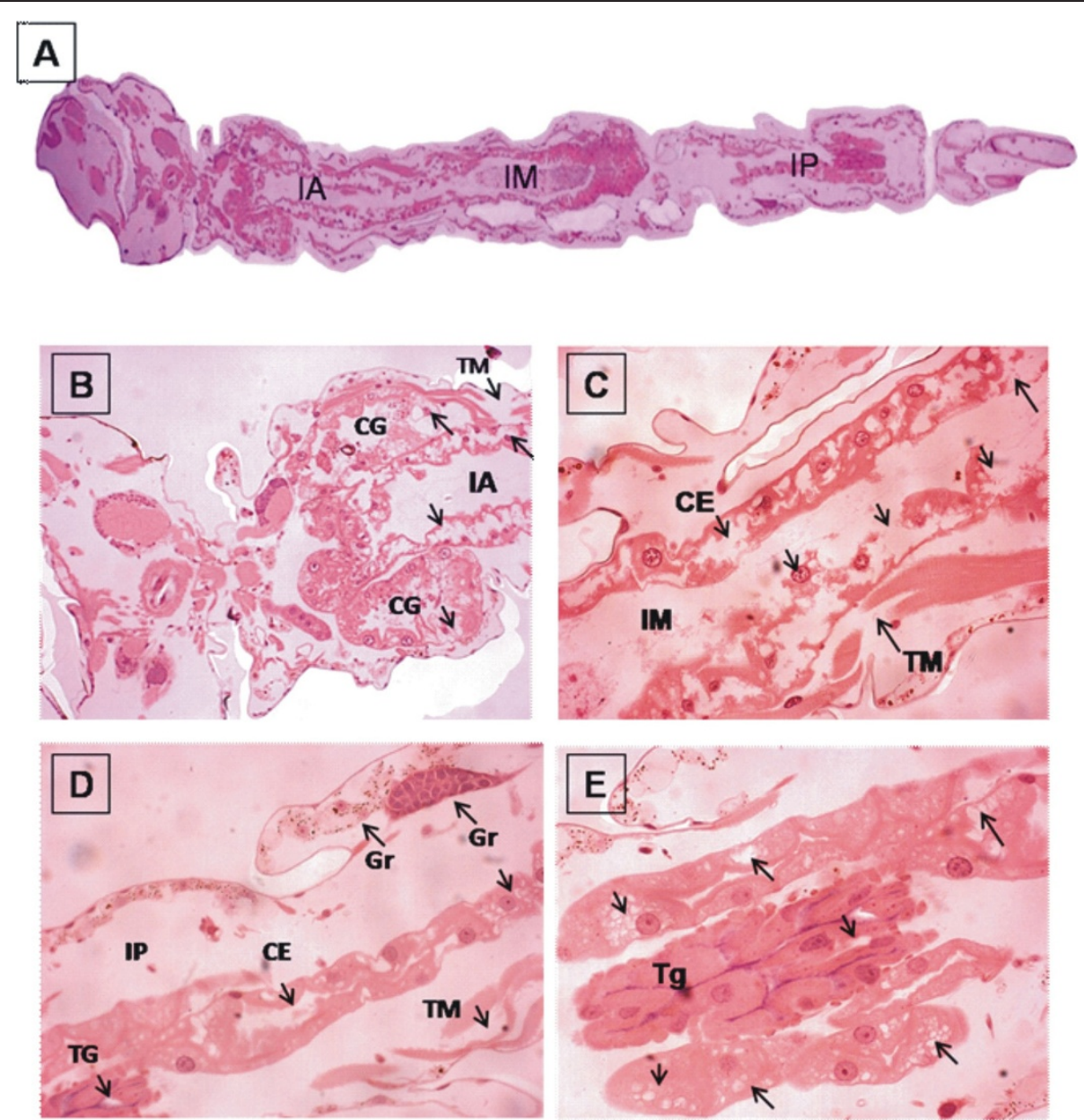

Figure 3 Photomicrographs of the midgut of third instar larvae of $A$. aegypti maintained with food and treated with Burchellin. Longitudinal sections stained with HE. A. Overview of foregut (IA), midgut (IM), hindgut (IP) 20X. B. Vacuolization in gastric caeca (CG) and cellular disorder, muscle tissue with breakpoints (TM) and vacuolated cells in the foregut showing spaces between them (IA) 40X. C. Midgut (IM), alteration of basal epithelial cells of the intestine (EC), break points of the muscle tissue (TM) 40X. D. Hindgut (IP), disorder of epithelial cells (EC), granule formation (arrows), disruption of muscle tissue (TM) and vacuoles in the Malpighian tubules (TG) 40X. E. Detail of the Malpighian tubules with vacuoles and intracellular spacing (TG) 40X. 
attractive for its marketing as a natural alternative for the control of mosquitoes. On the basis of histomorphological analysis, burchellin demonstrated targeted interference, acting on small specific regions of the larva, helping us understand the toxicity of the substance related to the site of action of the neolignan. Thus, burchellin appears to be a potent biolarvicide of natural origin and a safe and stable compound, in the control of $A$. aegypti, the principal mosquito transmitter of dengue and urban yellow fever.

\section{Conclusion}

The neolignan burchellin proved to be a strong candidate for a natural, safe and stable phytolarvicidal to be used in population control of $A$. aegypti.

\section{Competing interests}

The authors declare that they have no competing interests.

\section{Authors' contributions}

MM and JOAN conceived the idea for the study and wrote the manuscript; MM, JOAN, ROAS and JRSM performed the experimental assays. JMBF and MCOC isolated burchellin; AEG provided critical comments and participated in protocol drafting, results analysis and preparation of the discussion. All authors approved the final version of this manuscript.

\section{Acknowledgments}

This research was supported by grants from Fundação de Amparo a Pesquisa do Estado do Rio de Janeiro (FAPERJ) and Fundação para o Desenvolvimento Científico e Tecnológico em Saúde (FIOTEC/FIOCRUZ). The authors thank NApVe, (Parceira DIRAC-IOC-VPAAPS/FIOCRUZ) for the A. aegypti eggs and Dr. Marcelo Genestra (Laboratório de Bioquímica de Tripanossomatídeos, IOC/FIOCRUZ) for analysis of NADPH and NOS.

\section{Author details}

'Laboratório de Diptera, Instituto Oswaldo Cruz, FIOCRUZ, Av. Brazil 4365, Rio de Janeiro 21045-900, Brazil. Laboratório de Biologia Molecular e Doenças Endêmicas, Instituto Oswaldo Cruz, FIOCRUZ, Av. Brazil 4365, Rio de Janeiro 21040-360, Brazil. 'aboratório de Transmissores de Leishmanioses, Setor de Entomologia Médica e Forense, Instituto Oswaldo Cruz, Av. Brasil 4365, 21040-360 Rio de Janeiro, Brazil. ㄴaboratório de Tecnologia Farmacêutica, Universidade Federal da Paraíba, C. P. 5009, 58051-970 João Pessoa, PB, Brazil. ${ }^{5}$ Laboratório de Insetos Vetores, Ciências da Saúde and Mestrado Profissional em Ciências Ambientais, Universidade Severino Sombra, Av. Expedicionário Oswaldo de Almeida Ramos, 280, 27700-000 Vassouras, RJ, Brazil.

Received: 12 June 2013 Accepted: 31 March 2014

Published: 8 April 2014

\section{References}

1. Teixeira MG, Barreto ML, Costa MCN, Ferreira LDA, Vasconcelos PFC, Caincross S: Dynamics of dengue virus circulation: a silent epidemic in a complex urban area. Trop Med Int Health 2002, 7:757-762.

2. WHO: Dengue Hemorrhagic Fever: Diagnosis, Treatment, Prevention and Control. 2nd edition. Geneva, Switzerland: World Health Organization; 1997.

3. Christophers SR: Aedes aegypti (L.). The yellow fever mosquito. In Its life history, bionomics and structure. London: Cambridge University Press; 1960:739.

4. Bentley MD, Day JF: Chemical ecology and behavioral aspects of mosquito oviposition. Annu Rev Entomol 1989, 34:401-421.

5. Park IK, Schin SC, Park JD, Ahn YJ: Larvicidal activity of isobutylamides identified in Piper nigrum fruits against three mosquito species. J Agric Food Chem 2002, 50:1866-1870.

6. Maleck M, Santos FCC, Serdeiro MT, Guimarães AE, Ferreira B, Gunaydin K, Almeida AP: Kellin: a furanochromone with toxicity against Oncopeltus fasciatus (Hemiptera) and Aedes aegypti (Diptera). J Nat Pharmac 2013, 4:32-36.
7. Cabral MMO, Garcia ES, Kelecom A: Lignans from the Brazilian Melia azedarach and their activity in Rhodnius prolixus (Hemiptera, Reduviidae). Mem Inst Oswaldo Cruz 1995, 90:759-763.

8. Silva HHG, Silva IG, Santos RMG, Filho ER, Elias CN: Larvicidal activity of tannins isolated of Magonia pubescens St. Hil. (Sapindaceae) against Aedes aegypti (Diptera, Culicidae). Rev Soc Bras Med Trop 2004, 37:396-399.

9. Cabral MMO, Alencar JA, Guimarães AE, Kato MJ: Larvicidal activity of grandisin against Aedes aegypti. J Am Mosq Cont Ass 2009, 25:103-105.

10. Cabral MMO, Azambuja P, Gottlieb OR, Garcia ES: Effects of lignans and neolignans on the development and excretion of Rhodnius prolixus. Fitoterapia 2000, 71(Suppl b):1-9.

11. Cabral MMO, Mendonça PM, Gomes CMS, Barbosa Filho JM, Dias CS, Soares MJ, Queiroz MMC: Biological activity of yangambin on the postembryonic development of Chrysomya megacephala (Diptera: Calliphoridae). J Med Entomol 2007, 44(Suppl 2a):249-255.

12. Cabral MMO, Mendonça PM, Gomes CMS, Barbosa FJM, Queiroz MMC, Mello RP: Biological activity of neolignans on the post-embryonic development of Chrysomya megacephala (Diptera: Calliphoridae). Fitoterapia 2007, 78(Suppl b):20-24.

13. Evans DA, Kaleysa R: Effect of quassin on the metabolism of catecholamines in different life cycle stages of Culex quinquefasciatus. Indian J Biochem Bioph 1992, 29:360-363.

14. Cabral MMO, Kollien A, Kleffmann T, Azambuja P, Gottlieb OR, Garcia ES, Schaub AG: Rhodnius prolixus: Effects of the neolignan burchellin on in vivo and in vitro diuresis. Parasitol Res 2000, 86(Suppl a):710-716.

15. Nogueira CDR, Mello RP, Kato MJ, Cabral MMO: Disruption of Chrysomya megacephala growth caused by lignan grandisin. J Med Entomol 2009, 46:281-283.

16. Sukumar K, Perich MJ, Boobar LR: Botanical derivatives in mosquito control: a review. J Am Mosa Control Assoc 1991, 7:210-237.

17. Alkofahi A, Rupprecht JK, Anderson JE, McLaughlin JL, Mikolajczak KL, Scott BA: In Search for new pesticides from higher plants. Edited by Arnason JT, Philogène BJR, Morand P. Washington, D.C: Insecticides of plant origin. ACS Symp. Ser, vol. 387. American Chemical Society; 1989. 3:25-43.

18. George DR, Finn RD, Graham KM, Sparagano OAE: Present and future potential of plant-derived products to control arthropods of veterinary and medical significance. Parasit Vectors 2014, 7:28.

19. Cabral MMO, Azambuja P, Gottlieb OR, Kleffmann T, Garcia ES, Schaub GA: Burchellin: effects on Triatoma infestans and on Trypanosoma cruzi within this vector. Parasitol Res 2001, 87:730-735.

20. Chauret DC, Bernard CB, Arnason JT, Durst T: Insecticidal neolignans from Piper decurrens. J Nat Prod 1996, 59:152-155.

21. Richie JP, Mills BJ, Lang CA: Dietary nordihydroguaiaretic acid increases the life span of the mosquito. Proc Soc Exp Biol Med 1986, 183:81-85.

22. Cabral MMO, Barbosa-Filho JM, Maia GLA, Chaves MCO, Braga MV, De Souza W, Soares ROA: Neolignans from plants in Northeastern Brazil (Lauraceae) with activity against Trypanosoma cruzi. Exp Parasitol 2010, 124:319-324.

23. Araújo-Lima O, Gottlieb OR, Magalhães MT: Burchellin, a neolignan from Aniba burchelli. Phytochemistry 1972, 11:2031-2037.

24. Buechi G, Mak CC: Nitro olefination of indoles and some substituted benzenes with 1-dimethylamino-2-nitroethylene. J Org Chem 1977, 42:1784-1786.

25. Leite ACFC, Kato MJ, Soares ROA, Guimarães AE, Santos-Mallet JR, Cabral MMO: Grandisin caused morphological changes larval and toxicity on Aedes aegypti. Braz J Pharmacogn 2012, 22:517-521.

26. WHO: Insecticide resistance and vector control. In World Health Organization Technical Reports Series. Geneva, Switzerland; 1970:443.

27. Sokal RR, Rohlf FJ: Principios y Metodos Estatísticos em la Investigación Biológica. Madri, España: H. Blume Ed; 1979:223pp.

28. Motulsky HJ: Analyzing data with Graphpad Prism. San Diego, CA: GraphPad Software Inc; 2002.

29. Hamilton MA, Russo RV: Trimmed Spearman-Karber method for estimating median lethal concentrations in bioassays. Thurston Environ Sci Technol 1978, 12:417.

30. Bancroft JD, Stevens A: Tissue processing. In Theory and practice of histological techniques. 4th edition. New York: Churchill Livingstone; 1996:83-92. Cap. 6

31. Genestra M, Souza WJ, Guedes-Silva D, Machado GM, Cysne-Finkelstein L, Bezerra RJ, Monteiro F, Leon LL: Nitric oxide biosynthesis by Leishmania amazonensis promastigotes containing a high percentage of metacyclic forms. Arch Microbiol 2006, 185:348-354. 
32. Monte-Neto RL, Barbosa-Filho JM, Souza LMA, Athayde Filho PF, Dias CS, Oliveira MR: Crude ethanolic extract, lignoid fraction and yangambin from Ocotea duckei (Lauraceae) show antileishmanial activity. Z Naturforsch 2006, 62c:348-352.

33. Park IK, Shin SC, Kim CS, Lee HJ, Choi WS, Ahn YJ: Larvicidal activity of lignans identified in Phryma leptostachya var. Asiatic roots against three mosquito species. J Agric Food Chem 2005, 53:969-972.

34. Solis P, Olmedo D, Nakamura O, Calderon Al, Hattori M, Gupta MP: A new larvicidal lignan from Piper fimbriulatum. Pharmac Biol 2005, 43:378-381.

35. March J: Reactions mechanisms and structure. In Advanced Organic Chemistry. 3rd edition. New York: John Wiley \& Sons; 1985:134.

36. Moser BA, Becnel JJ, White SE, Alfonso C, Kutish G, Shanker S, Almira E: Morphological and molecular evidence that Culex nigripalpus baculovirusis an unusual member of the family Baculoviridae. J Gen Virol 2001, 82:283-297.

37. Silva VC, Pinheiro NL, Scherer PO, Falcão SS, Ribeiro VR, Mendes RMM, Chagas R, De Almeida MC, Mallet JRS: Histology and ultrastructure of Aedes albopictus larval midgut infected with Bacillus thuringiensis var. israelensis. Microsc Res Tech 2008, 71:663-668.

38. Snodgrass RE: Principles of insect morphology. 1st edition. New York: McGraw-Hill Book Company; 1935.

doi:10.1186/1756-3305-7-172

Cite this article as: Narciso et al: Burchellin: study of bioactivity against Aedes aegypti. Parasites \& Vectors 2014 7:172.

\section{Submit your next manuscript to BioMed Central and take full advantage of:}

- Convenient online submission

- Thorough peer review

- No space constraints or color figure charges

- Immediate publication on acceptance

- Inclusion in PubMed, CAS, Scopus and Google Scholar

- Research which is freely available for redistribution 